\title{
Effects of percutaneous estradiol-oral progesterone versus oral conjugated equine estrogens-medroxyprogesterone acetate on breast cell proliferation and bcl-2 protein in healthy women
}

\begin{abstract}
In a prospective, randomized clinical study 77 women were assigned randomly to receive sequential hormone therapy with either conventional oral conjugated equine estrogens $(0.625 \mathrm{mg})$ with the addition on 14 of the 28 days of oral medroxyprogesterone acetate $(5 \mathrm{mg})$ or natural $\mathrm{E}_{2}$ gel $(1.5 \mathrm{mg})$ with oral micronized $\mathrm{P}(200 \mathrm{mg})$ on 14 of the 28 days of each cycle. Because oral conjugated equine estrogens-medroxyprogesterone acetate induced a highly significant increase in breast cell proliferation in contrast to percutaneous $\mathrm{E}_{2}$-oral $\mathrm{P}$ with a difference between therapies approaching significance, the former therapy has a marked impact on the breast whereas natural percutaneous $E_{2}$-oral micronized $\mathrm{P}$ has not. (Fertil Steril ${ }^{\circledR}$ 2011;95:1188-91. @2011 by American Society for Reproductive Medicine.)
\end{abstract}

Key Words: Percutaneous estradiol, micronized progesterone, HT, proliferation, bcl-2 protein, normal breast tissue

Postmenopausal hormone therapy (HT) has been associated with an increased risk for breast cancer. The risk with combined estrogen-progestogen therapy is greater than with estrogen alone

Daniel Murkes, M.D. ${ }^{\mathrm{a}}$

Peter Conner, M.D., Ph.D. ${ }^{\text {b }}$

Karin Leifland, M.D., Ph.D. ${ }^{\mathrm{c}}$

Edneia Tani, M.D., Ph.D. ${ }^{\mathrm{d}}$

Aude Beliard, M.D., Ph.D. ${ }^{\mathrm{e}}$

Eva Lundström, M.D., Ph.D. ${ }^{\text {b }}$

Gunnar Söderqvist, M.D., Ph.D. ${ }^{\mathrm{b}}$

${ }^{a}$ Department of Obstetrics and Gynecology, Södertälje

Hospital, Södertälje, Sweden

${ }^{b}$ Department of Obstetrics and Gynecology, Karolinska

Hospital, Stockholm, Sweden

${ }^{c}$ Unilabs Mammography, Capio St. Göran's Hospital, Stockholm, Sweden

${ }^{d}$ Department of Pathology and Cytology, Karolinska Hospital, Stockholm, Sweden

${ }^{e}$ Department of Obstetrics and Gynecology, University of Liège, Liège, Belgium

Received January 22, 2010; revised August 14, 2010; accepted September 28, 2010; published online November 10, 2010.

D.M. has nothing to disclose. P.C. has nothing to disclose. K.L. has nothing to disclose. E.T. has nothing to disclose. A.B. has nothing to disclose. E.L. has nothing to disclose. G.S. has nothing to disclose.

Supported by grants from the Swedish Cancer Society, the Swedish Research Council (Project No. 5982), the Karolinska Institutet Research Funds, and an unrestricted grant from Besins Healthcare, Brussels, Belgium.

Reprint requests: Gunnar Söderqvist, M.D., Ph.D., Department of Woman and Child Health, Division for Obstetrics and Gynecology, Karolinska University Hospital/Institutet, SE-171 76 Stockholm, Sweden (E-mail: gunnar.soderqvist@karolinska.se).
(1-6). Hormone therapy is not a uniform concept, and various preparations, doses, and regimens of HT may have different effects (7). Although estrogen is a known mitogen in the breast, the effects of added progestogens may vary considerably (8-15), but proliferative responses are seen within 2 months (9-11). Synthetic progestogens may differ from natural P. In the French $\mathrm{E} 3 \mathrm{~N}$ cohort, women taking estrogen in combination with micronized $\mathrm{P}$ were found to have no increase in breast cancer risk in contrast to women taking estrogen in combination with synthetic progestogens $(16,17)$.

In this study we used core needle biopsy to evaluate breast cell proliferation in healthy postmenopausal women during two different types of sequential HTs: oral conjugated estrogens plus synthetic progestogen versus percutaneous $\mathrm{E}_{2}$ plus natural oral micronized $\mathrm{P}$. A prospective randomized clinical study was performed at the Karolinska University Hospital, Stockholm, Sweden, between May 2006 and March 2008. Apparently healthy women, aged 44 to 66 years, postmenopausal for at least 12 months, nonsmokers, with normal mammogram results, and with a body mass index of 18 to $30 \mathrm{~kg} / \mathrm{m}^{2}$, were recruited. Follicle-stimulating hormone levels at screening were $>25 \mathrm{IU} / \mathrm{L}$, and $\mathrm{E}_{2}$ levels $<90 \mathrm{pmol} / \mathrm{L}$. The washout period for previous HT users was 3 months.

Exclusion criteria were any breast disease, previous breast surgery, hepatic dysfunction, active gallbladder disease, or history of thromboembolic disease. Medication with sexual steroids, barbiturates, carbamazepines, phenytoin, glucocorticoids, rifampicin, cimetidine, diltiazem, erythromycin, ketoconazole, verapamil, and quinidine was not permitted.

The study was approved by the independent ethics committee IRB-2005/762-31 and the Swedish Medical Products Agency EU-2005/001016-51. All women gave their written informed consent. 
Seventy-seven women were assigned randomly to receive sequential HT with two 28-day cycles of either oral $0.625 \mathrm{mg}$ conjugated equine estrogens or $2.5 \mathrm{~g} 0.06 \%$ percutaneous $\mathrm{E}_{2}$ gel $(1.5 \mathrm{mg} \mathrm{E}$ ), daily, with the addition of respectively $5 \mathrm{mg}$ of oral medroxyprogesterone acetate (MPA) or $200 \mathrm{mg}$ of oral P, daily, for the last 14 days of each cycle.

Two percutaneous stereotactic core needle biopsies were performed before treatment and during one of the last 3 days of the second 28-day treatment cycle, respectively, with the patient under local anesthesia on a prone table (Lorad, DSM, Danbury, CT) in the upper outer quadrant of the left breast. The biopsies were paraffin embedded and sectioned at $5 \mu \mathrm{m}$ until dewaxed and immunostained.

Immunostained cells were quantified with use of cell counting of all available positive and negative cells and fields by two observers blinded to treatment with the Ki-67/MIB-1 monoclonal antibody (Bench Mark, Ventana Medical Systems, Illkirch Cedex, France) (18). The procedure uses an avidin-biotin peroxidase system in a Bench Mark staining module, which is a fully computerized system that performs deparaffinization, antigen retrieval, staining with amplification, and counterstaining in a standardized and reproducible fashion. Samples containing $\geq 50$ breast epithelial cells were considered evaluable. Immunostaining for the antiapoptotic protein bcl-2 was performed with use of the commercially available antibody bcl-2 clone 124 ( $\mathrm{nr} 760-4246$; Cell Marque Corp., Rocklin, CA) (19).
Circulating sex steroid levels and sex hormone-binding globulin before treatment and on one of the last 3 days of the second 28-day treatment cycle were quantified by routine hospital methods. Concentrations of free T were calculated as described earlier (20).

The detection limits and within- and between-assay coefficients of variation for $\mathrm{T} 0.1 \mathrm{nmol} / \mathrm{L}$ were $6 \%$ and $12 \%$, for sex hormonebinding globulin $0.2 \mathrm{nmol} / \mathrm{L} 6.5 \%$ and $8.7 \%$, for $\mathrm{E}_{2}$ Spectria $5 \mathrm{pmol} / \mathrm{L} 7.4 \%$ (Orion Diagnostica Oy, Espoo, Finland) and $10.3 \%$, for $\mathrm{E}_{2}$ Immulite $55 \mathrm{pmol} / \mathrm{L}$ 9.3\% (Diagnostic Products Corporation, Los Angeles, CA) and 10.6\%, and for P $0.6 \mathrm{nmol} / \mathrm{L} 8.2 \%$ and $9.3 \%$.

Differences between the two treatment groups were assessed with use of the Mann-Whitney test. For within-group changes the Wilcoxon signed-rank test was used. Correlations were assessed by Spearman's rank correlation test. A $P$ value $<.05$ was considered statistically significant.

In total, 99 women were tested for eligibility. Twenty-two women were excluded for not meeting the inclusion criteria. Seventy-seven women were assigned randomly. A total of 71 women, 37 receiving conjugated equine estrogens-MPA and 34 receiving $\mathrm{E}_{2}-\mathrm{P}$, completed the study.

From the 71 women a total of 284 core needle biopsy specimens were collected. Forty of the 71 women $(56 \%)$ had assessable samples at baseline, 53 of $71(75 \%)$ at 2 months, and 35 of $71(49 \%)$ both at baseline and after 2 months. There were no significant differences between treatment groups in mean age, body mass index,

\section{FIGURE 1}

Breast histologic findings from two individual women before (left) and after (right) 2 months of sequential treatment with either oral conjugated equine estrogens-MPA (top) or percutaneous $\mathrm{E}_{2}$-oral micronized P (bottom). Nuclei of proliferating cells staining brown by Ki-67 MIB-1 antibody. (Original magnification $\times 200$.)
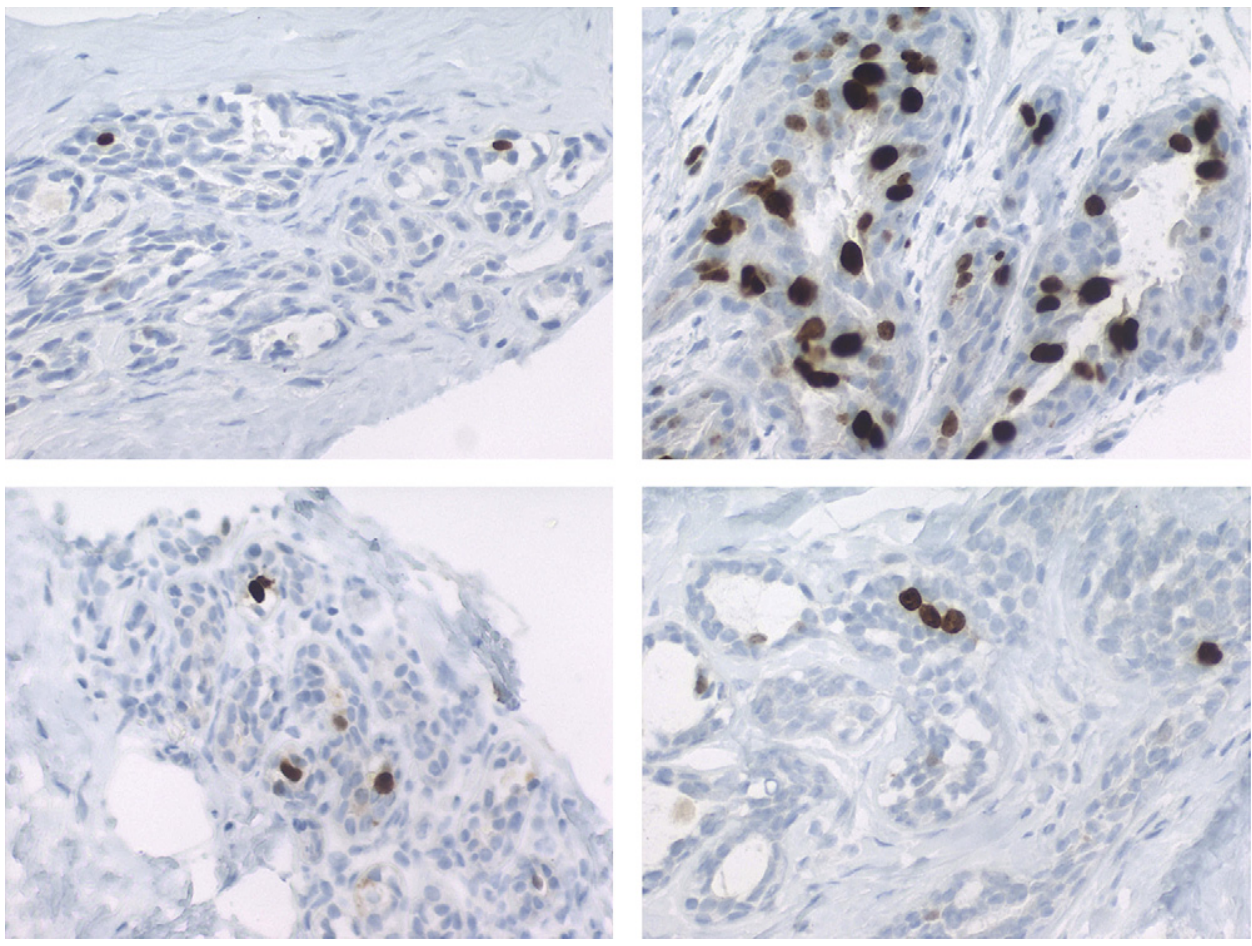

Murkes. Correspondence. Fertil Steril 2011. 
parity, years since menopause, proportion of Ki-67-positive cells or bcl-2-positive cells, or serum hormone levels at baseline.

After 2 months of treatment, conventional HT, that is, conjugated equine estrogens-MPA orally, increased proliferation more than treatment with natural percutaneous $\mathrm{E}_{2}$ in combination with oral $\mathrm{P}$, at borderline significance $(P=.05)$. The conventional therapy induced a highly significant increase in proliferation from mean $1 \%$, median $0.6 \%$, and range $0 \%$ to $4 \%$ at baseline to mean $10.0 \%$, median $2.6 \%$, and range $0 \%$ to $56 \%$ of proliferating normal breast epithelial cells after 2 months of treatment $(P=.003)$. In contrast, treatment with percutaneous $\mathrm{E}_{2}$-oral $\mathrm{P}$ did not significantly increase proliferation (mean $3.1 \%$, median $1.4 \%$, range $0 \%$ to $21.5 \%$ at baseline vs. mean $5.8 \%$, median $1.8 \%$, and range $0 \%$ to $39 \%$ at 2 months) (Fig. 1). This proliferative response of sequential conjugated equine estrogens-MPA is similar to that of conventional continuous combined treatment found in earlier studies $(12,15,21,22)$ whereas the natural $\mathrm{E}_{2}-\mathrm{P}$ therapy did not increase breast cell proliferation significantly in conformity with previous findings (23). Increased proliferation during HT must be regarded as an unwanted potentially hazardous side effect whereas increased apoptosis reasonably is beneficial. The proportion of bcl-2-positive cells was numerically down-regulated during both therapies approaching significance $(P=.06)$ for the natural regimen from mean $49 \%$, median $50 \%$, and range $0 \%$ to $100 \%$ before treatment to mean $26 \%$, median $40 \%$, range $0 \%$ to $80 \%$ at 2 months. The conjugated equine estrogens-MPA group values for bcl-2 were mean $46 \%$, median $60 \%$, range $0 \%$ to $90 \%$ (baseline) versus mean $27 \%$, median $20 \%$, range $0 \%$ to $80 \%$ ( 2 months) without between-groups difference. Downregulation became significant for the total material of both treatments $(P=.01)$, thus facilitating apoptosis.

In this study conjugated equine estrogens plus MPA orally were found to increase proliferation more than treatment with natural percutaneous $\mathrm{E}_{2}$ in combination with oral $\mathrm{P}$, only at borderline significance. The power calculations before the study were based on the assumption of a yield of at least $55 \%$ assessable samples both before and after treatment as found by us earlier with fine-needle aspiration biopsies $(12,21,24)$, resulting in the need for 70 women to fulfill the study. However, with core needle biopsy, unexpectedly, only $49 \%$ of the women had assessable breast epithelium in biopsies both before and after 2 months of treatment.

Although progestogens have been identified as a potential risk factor, there are indications of important differences between preparations. In the French E3N cohort there was an absence of breast cancer risk increase for women taking estrogen in combination with natural $P$ for at least 5 years of treatment $(17,25)$. This is in line with the indication in the current study of a higher proliferative activity in the breast imposed by oral conjugated equine estrogens-MPA versus percutaneous $E_{2}-$ micronized $P$ orally, maintaining an $\mathrm{E}_{2}$ dose of $1.5 \mathrm{mg}$ daily, which is needed by many women at least in an initial phase of postmenopausal symptoms.

Not only natural $\mathrm{P}$ but also $\mathrm{E}_{2}$ given through the transdermal route may add to the less-adverse effects on the breast compared with the conventional oral therapy. In the large General Practitioners Research Database no increase in risk for breast cancer was observed when opposed estrogens were given transdermally in contrast to estrogens given orally (26-28).

Although we now have found it clearly less proliferative than MPA, it is important to stress that $\mathrm{P}$ was not found to be antiproliferative in normal breast tissue (9). Furthermore, both MPA and P have been found to reactivate stem cells with potential for malignancy, in vitro, but the clinical implications of this finding for women are not elucidated (29). Recently we reported that so far the only antiproliferative drug in normal breast tissue in vivo is the anti-P mifepristone, which significantly reduced breast cell proliferation in premenopausal women (30).

The long-term safety of combined HT especially in the breast has been discussed vividly over the past decades. The need is strong to define treatment regimens and alternatives for postmenopausal women that have minimal effects on the breast but still allow effective symptom relief.

The study does not answer whether the estrogenic or progestogenic component of HT, or a synergy between both, gives the more beneficial effect with use of natural treatment. However, for millions of women with severe climacteric symptoms, we need to find and evaluate efficient HTs with as low impact on the breast as possible. The findings of this study suggest that 2 months of treatment with percutaneous $\mathrm{E}_{2}$ in combination with 14 of 28 days of micronized $\mathrm{P}$ has less-adverse effects on normal human breast proliferation in vivo, and it also seems to facilitate apoptosis.

Acknowledgments: Technical assistance was provided by Birgitta Byström, Berit Legerstam, Torsten Hägerström, Eva Andersson, Siv Rödin, and Lotta Blomberg.

\section{REFERENCES}

1. Rossouw JE, Anderson GL, Prentice RL, LaCroix AZ, Kooperberg C, Stefanick ML, et al. Writing Group for the Women's Health Initiative Investigators. Risks and benefits of estrogen plus progestin in healthy postmenopausal women: principal results from the Women's Health Initiative randomized controlled trial. J Am Med Assoc 2002;288:321-33.

2. Beral V. Breast cancer and hormone-replacement therapy in the Million Women Study. Lancet 2003;362:419-27.

3. Santen RJ, Pinkerton J, McCartney C, Petroni GR. Risk of breast cancer with progestins in combination with estrogen as hormone replacement therapy. J Clin Endocrinol Metab 2001;86: $16-23$.
4. Weiss LK, Burkman RT, Cushing-Haugen KL, Voigt LF, Simon MS, Daling JR. Hormone replacement therapy regimens and breast cancer risk. Obstet Gynecol 2002;100:1148-58.

5. Prentice RL, Chlebowski RT, Stefanick ML, Manson JE, Langer RD, Pettinger M, et al. Estrogen plus progestin therapy and breast cancer in recently postmenopausal women. Am J Epidemiol 2008;167: 1207-16.

6. Chlebowski RT, Hendrix SL, Langer RD, Stefanick ML, Gass M, Lane D, et al., for the WHI investigators. Influence of estrogen plus progestin on breast cancer and mammography in healthy postmenopausal women: the Women's Health Initiative randomized trial. J Am Med Assoc 2003;289:3242-53.
7. Greendale GA, Reboussin BA, Sie A, Singh HR, Olson LK, Gatewood $\mathrm{O}$, et al. Effects of estrogen and estrogen-progestin on mammographic parenchymal density. Ann Intern Med 1999;130:262-9.

8. Gompel A, Malet C, Spritzer P, Lalardrie JP, Kuttenn F, Mauvais-Jarvis P. Progestin effect on cell proliferation and $17 \beta$-hydroxysteroid dehydrogenase activity in normal human breast cells in culture. J Clin Endocrinol Metab 1986;63: 1174-80.

9. Söderqvist G, Isaksson E, von Schoultz B, Carlström K, Tani E, Skoog L. Proliferation of breast epithelial cells in healthy women during the menstrual cycle. Am J Obstet Gynecol 1997;176: $123-8$. 
10. Isaksson E, von Schoultz E, Odlind V, Söderqvist G, Csemiczky G, Carlström K, et al. Effects of oral contraceptives on breast epithelial proliferation. Breast Cancer Res Treat 2001;65:163-9.

11. Lundström E, Söderqvist G, Svane G, Azavedo E, Olofsson M, Skoog L, et al. Digitized assessment of mammographic breast density in patients who received low-dose intrauterine levonorgestrel in continuous combination with oral estradiol valerate: a pilot study. Fertil Steril 2006;85:989-95.

12. Conner P, Christow A, Kersemaekers W, Söderqvist G, Skoog L, Carlström $\mathrm{K}$, et al. A comparative study on breast cell proliferation during hormone replacement therapy. Effects of tibolone and combined estrogen-progestogen treatment. Climacteric 2004;7:50-8.

13. Preston-Martin S, Pike MP, Ross RK, Jones PA, Henderson BE. Increased cell division as a cause of human cancer. Cancer Res 1990;50: 7415-21.

14. Conner P, Register TC, Skoog L, Tani E, von Schoultz B, Cline JM. Expression of P53 and markers of apoptosis in breast tissue during long-term hormone therapy in cynomolgus monkeys. Am J Obstet Gynecol 2005;193: 58-63.

15. Valdivia I, Campodonico I, Tapia A, Capetillo M, Espinoza A, Lavin P. Effects of tibolone and continuous combined hormone therapy on mammographic breast density and breast histochemical markers in postmenopausal women. Fertil Steril 2004;81:617-23.
16. Foidart JM, Colin C, Denoo X, Desreux J, Béliard A, Fournier S, et al. Estradiol and progesterone regulate the proliferation of human breast epithelial cells. Fertil Steril 1998;69:963-9.

17. Fournier S, Berrino F, Clavel-Chapelon F. Unequal risks for breast cancer associated with different hormone replacement therapies. Breast Cancer Res Treat 2008;107:103-11.

18. Gerdes J, Li L, Schlueter C, Duchrow M, Whienberg C, Gerlach C, et al. Immunobiochemical and molecular biologic characterization of the cell proliferation-associated nuclear antigen that is defined by monoclonal antibody Ki-67. Am J Pathol 1991;138:867-73.

19. Gompel A, Somai S, Chaouat M, Kazem A, Kloosterboer HJ, Beusman I, et al. Hormonal regulation of apoptosis in breast cells and tissues. Steroids 2000;65:593-8.

20. Södergård R, Bäckström $T$, Shanbag V, Carstensen $\mathrm{H}$. Calculation of free and bound fractions of testosterone and estradiol-17 $\beta$ to plasma proteins at body temperature. J Steroid Biochem 1982;18:801-4.

21. Hofling M, Linden-Hirschberg A, Skoog L, Tani E, Hägerström T, von Schoultz B. Testosterone inhibits estrogen/progestogen induced breast cell proliferation in postmenopausal women. Menopause 2007; 14:183-90.

22. Conner P, Söderqvist G, Skoog L, Gräser T, Walter F, Tani E, et al. Breast cell proliferation in postmenopausal women during HRT evaluated through fine needle aspiration biopsy. Breast Cancer Res Treat 2003;78:159-65.
23. Wood CE, Register T, Lees CJ, Chen H, Kimrey S, Cline JM. Effects of estradiol with micronized progesterone or medroxyprogesterone acetate on risk markers for breast cancer in postmenopausal monkeys. Breast Cancer Res Treat 2007;101:125-34.

24. Conner P, Skoog L, Söderqvist G. Breast epithelial proliferation in postmenopausal women evaluated through fine-needle aspiration cytology. Climacteric 2001;4:7-12.

25. Fournier A, Mesrine S, Boutron-Ruault MC, ClavelChapelon F. Estrogen-progestagen menopausal hormone therapy and breast cancer: does delay from menopause onset to treatment initiation influence risks? J Clin Oncol 2009;27:5138-43.

26. Opatrny L, Dell'Aniello S, Assouline S, Suissa S. Hormone therapy use and variations in the risk of breast cancer. Br J Obstet Gynaecol 2008;115: 169-75.

27. Conner P, Lundström E, von Schoultz B. Breast cancer and hormonal therapy. Clin Obstet Gynecol 2008;51:592-606.

28. Willet WC, Colditz G, Stampfer M. Postmenopausal estrogens-opposed, unopposed, or none of the above. J Am Med Assoc 2000;283:534-5.

29. Horwitz KB, Sartorius CA. Progestins in hormone replacement therapies reactivate cancer stem cell in women with pre-existing breast cancers: a hypothesis. J Clin Endocrinol Metab 2008;93:3295-8.

30. Engman M, Skoog L, Söderqvist G, Gemzell K. The effect of mifepristone on breast cell proliferation in premenopausal women evaluated through fine needle aspiration cytology. Hum Reprod 2008;23: 2072-9. 